\title{
Novel Modelling of the Operation of the Financial Intermediary System - Agent-based Macro Models*
}

\author{
Bence Mérő
}

The study describes three agent-based macro models - expanded with the banking sector - that may later, following adequate further development, serve as bases for regulatory decisions. By presenting and explaining these models, the author attempts to make the readers understand the nature, essence and framework of agent-based modelling, also highlighting the difficulties that arise during modelling.

Journal of Economic Literature (JEL) codes: B52, E44, Y2

Keywords: agent-based modelling, banking sector, money creation

\section{Introduction}

As a result of the financial crisis, the need increased to develop models that allow for the examination of the role of lending in terms of real economy feedbacks and with which it is possible to model the operation of the financial intermediary system taking account of various regulatory requirements, with particular regard to macroprudential regulation, which serves financial stability.

In the light of experiences, more and more mainstream models include financial frictions (e.g. Gertler and Kiyotaki 2010, Gertler and Karádi 2011, Christiano et al. 2010, 2014, Cúrdia and Woodford 2016, Lindé et al. 2016). The vast majority of dynamic stochastic general equilibrium (DSGE) models model banks as financial intermediaries, which disburse savings as loans. However, in the actual functioning of the economy, the banking sector creates the deposits in parallel with the disbursement of loans (McLeay et al. 2014). This approach is introduced into the DSGE models by Benes et al. (2014) as well as Jakab and Kumhof (2015). The latter also generates credit cycles, which are important in terms of macroprudential policy, although this requires several consecutive, independent exogenous shocks that are * The papers in this issue contain the views of the authors which are not necessarily the same as the official
views of the Magyar Nemzeti Bank.

Bence Mérő is an Economic Analyst at Magyar Nemzeti Bank, and an Assistant Lecturer at Corvinus University of Budapest.E-mail: merob@mnb.hu

The Hungarian manuscript was received on 22 June 2018.

DOI: http://doi.org/10.33893/FER.18.3.83113 
not foreseen by the actors at all, i.e. even when the individual shocks occur, they do not expect another one for the coming period.

The nature of lending and in particular the ensuing systemic risks are based on households' and corporations' considerable heterogeneity. While in previous DSGE models in many cases lending was constituted by the interaction of only two types of households, a patient one and an impatient one, for the modelling of lending risks it is necessary to increase the heterogeneity of the actors. The HANK (Heterogeneous Agent New Keynesian) models expand heterogeneity further, introducing a continuum of households (e.g. Kaplan et al. 2018).

It is partly the actors' bounded rationality that may result in the evolution of imbalances, which are determinants in terms of the riskiness of the banking sector as well. Bounded rationality changes the expectations in the mainstream macro models. De Grauwe's (2012) model, which rests on new Keynesian foundations, contains a behavioural economics approach as well, and by the inclusion of simple heuristics it is able to generate cycles in output in an endogenous manner. In the model of Békési et al. (2016), households' expectations concerning real income and the real interest rate are not model consistent, but they assume that they reach their steady state values in a specific quarter.

DSGE models are also able to model regulatory issues concerning the banking sector: Chadha and Corrado (2012) examine the liquidity aspects of macroprudential policy in their mainstream model, while Alpanda et al. (2018) developed a DSGE model in which monetary and macroprudential policies are analysed together.

The aforementioned examples suggest that by using various techniques it is possible to make DSGE models much more realistic, and researchers are working to create models in which both monetary and macroprudential policies can be analysed. Nevertheless, despite the significant achievements in individual areas, many leading economists are of the opinion that it is necessary to model the macroeconomy using other approaches as well (cf. Farmer and Foley 2009, Krugman 2011, Stiglitz 2011, Romer 2016). In parallel with this, so-called agent-based modelling has appeared as another approach in macroeconomics (cf. Tesfatsion and Judd 2006). Instead of solving the systems of equations of mainstream models, agent-based macro models consist of the simulation of the behaviour of economic agents: in their behaviour (e.g. in their consumption or production decisions), agents follow relatively simple rules of thumb one after the other.

Agent-based models model the economy setting out from heterogeneous actors. Of the different types of actors (such as households and companies), there may be several agents in the economy, and each agent has its own parameters and current state of its variables. The individual agents have bounded rationality, and they make 
their economic decisions on the basis of simple rules rather than by optimisation (and knowing the whole system). The aggregate variables evolve as a result of these decisions (bottom-up approach).

Upon determining the behavioural rules of individual actors, various behavioural economics results can be used, and accordingly, the economy can be modelled along increasingly realistic assumptions. Moreover, these assumptions are not limited by mathematical constraints: almost any rule can be introduced, and there is no need to keep the model manageable analytically or with the help of the current solving algorithms.

In view of the properties of agent-based modelling, at the level of assumptions everything is in place for an adequate treatment of the banking sector, correlation between lending and the real economy, lending risks stemming from the heterogeneity, the various micro- and macroprudential rules, etc. Agent-based models are bound by fewer constraints than mainstream models, and therefore they are able to provide a better mapping of reality. Accordingly, they allow for more reliable examination of the various monetary and macroprudential measures. Nevertheless, it would be too early to state that agent-based macro models will ever offer a better alternative, as they still need to develop significantly, and for the time being this direction of development also has to overcome many obstacles. In any case, it is worth reviewing what agent-based macro models are mentioned in the literature, as their further developed versions may (also) later be used to prepare various forecasts or to create regulations for the banking sector. Comprehensive descriptions of agent-based macro modelling are provided, for example, by Haldane and Turrell (2018), as well as Dawid and Delli Gatti (2018). Fagiolo and Roventini (2017) as well as Dilaver et al. (2018) compare agent-based macro models with mainstream models. The objective of this study is to exhibit during operation - by presenting three specific agent-based macro models - the possibilities inherent in this approach, with special regard to the functioning of the banking sector, because following further developments these types of models may also later serve as bases for regulatory decisions.

The next chapter provides a brief overview of the most important features of agent-based macro modelling, and the scope of agent-based macro models to be presented is also determined therein. In the subsequent chapters, the characteristics of the selected models are described. In light of own experiences obtained in the development of agent-based macro models, we comment on the models presented and on agent-based macro models in general, with a closing summary at the end. 


\section{About agent-based macro modelling in general}

According to Pyka and Fagiolo (2007), the construction of agent-based macro models is typically based on the following features:

1. Bottom-up approach: the model is based on economic agents' individual (micro level) decisions; macro level dynamics are the result of these decisions.

2. Heterogeneity: agents of the same type (e.g. companies or households) may be different from one another in various respects, which can be some simple variables (e.g. wealth or income) or even behavioural rules. Accordingly, the heterogeneous actors of the real economy are not substituted by a representative consumer (or company), but the individual actors make decisions separately, taking account of their peculiarities.

3. Bounded rationality: even if we disregard chance, the individual actors are not perfectly aware of the functioning of the economy, and thus their expectations are not necessarily model consistent. The decisions of individual actors are influenced by their expectations, but they can be formulated on the basis of very different rules. Learning may also be introduced into the models, e.g. the actors may change their expectation rules on the basis of experience. However, most often the agents apply some kind of adaptive expectation rule.

4. Direct (endogenous) interactions: agents' decisions may depend on the decisions of other agents (e.g. on neighbouring agents' decisions in the case of a spatial model), also including what other agents the individual agents establish contact with. Agents' relationship structure may also change over time.

5. Selection-based market mechanisms: in many cases agents may choose on the basis of market mechanisms who they establish contact with (e.g. what company a consumer purchases from), which may result in the closing-down of less profitable companies and the emergence of new firms.

The following characteristics follow from the above listed conditions:

6. Path-dependent dynamics: it follows from the adaptive expectations that the economy evolves in a path-dependent manner.

7. An evolving complex system approach: the actors of the model live in a complex system, which may change as time goes by.

8. Endogenous and persistent innovation: structural changes may evolve in an endogenous manner during the agents' decisions. 
Agent-based macro models consist of successive discrete periods, which are usually quarters or months. While in new Keynesian models everything is determined in a simultaneous manner in the individual periods, in agent-based models the events follow one another in a pre-determined order in every period, and previous events may affect later decisions. Accordingly, an agent-based model is a sequence of events. The logic of the model does not exclude the parallel occurrence of some events (for example, companies may make decisions in parallel with one another concerning the quantities to be produced).

Agent-based modelling is practically a computer simulation where the successive algorithms are programmed rather than deducing the equations of the model. Typically, an object-oriented programming language is used, as it is easy to match the agents to the objects. Each agent (object) has its own parameters and variables, which may change depending upon the developments in the model. And each agent has its own methods (which often depend on parameters or other variables), for example how a company decides on production in a given period or how a consumer decides on its consumption in a given period.

It is possible to create a wide range of modelling structures in agent-based macro models, but for the time being there are not many established rules as opposed to DSGE models. However, there is an unwritten rule in connection with the banking sector: agent-based macro models model the banking sector in a way that banks create deposits in parallel with the extension of loans, as it is in reality. It would be easy to incorporate the approach that banks lend on the savings, but as agentbased models would like to use assumptions that are as close to reality as possible, they immediately implement the real operating mechanism of the banking sector.

DSGE models are fully consistent models, which also relates to the accumulation of wealth, including the accumulation of capital and financial assets as well: it is clear from what resources the capital is created, and together with financial wealth, financial liability of the same degree also emerges immediately. The equations of the model automatically provide for the above. As agent-based modelling is not about solving equations, attention must be paid upon launching the model (when giving the initial values) that the pecuniary variables of the individual agents should be in harmony with one another at the macro level as well: an actor can have financial savings only if another one has debt, including banks' balance sheets as well. It also needs to be considered that the wealth of households, corporations and other actors should be in conformity with the real assets of the economy. And it must be taken into account not only when giving the initial values, but also upon updating the variables of each actor as well as during the various decisions and transactions. The models built up this way are called stock-flow consistent models. While DSGE models are inevitably stock-flow consistent as a result of budget constraints and equilibrium equations, special attention must be paid to this aspect in the case of 
agent-based models. Consistent modelling of financial assets and other components of wealth is greatly facilitated by the application of the balance sheet matrix and the transaction flow matrix. These matrices contain values aggregated by type of actor, and demonstrate in a transparent manner what other actors' debt the individual actors' wealth is coupled with in the given state of the model (balance sheet matrix), and how the components of wealth change during a given period (transaction flow matrix). In parallel with that, it is worth preparing the individual balance sheets of each type of actor as well.

Stock-flow consistent models are based on Copeland's (1949) quadruple entry principle: double-entry accounting is applied in the case of both participants of a transaction. Godley and Lavoie (2007) developed it further, and discuss the origin and flow of credit, money, income and wealth in a fully consistent framework within a Keynesian economy. Although their model is not agent-based, almost all of the models presented are based on their stock-flow consistent approach. This approach comprises endogenous money, which (in parallel with the monetary base) is created by lending, and banks create deposits by lending, and do not lend on the deposits collected before.

There are many types of agent-based macro models, but in recent years three approaches have started to emerge, which serve as a starting point for other research as well. One of the basic models was developed by Delli Gatti et al. (2011); their paper provides an intelligible and at the same time thorough introduction to the agent-based paradigm. The model is based on relatively simple rules, which provide a good illustration of the market adjustment mechanisms as well. The EURACE model (Deissenberg et al. 2008 and further developments), on the other hand, attempts to involve many segments of reality at the same time, but as a result, tracking the mechanisms is more difficult. Dosi et al. (2015) present a model which is sufficiently complex for examining fiscal and monetary policy issues as well, but the mechanisms still remain more or less transparent. The chapters below present an enhanced version of each model, which better focus on the banking sector.

In reviewing the models we present their basic assumptions, and in connection with their explanatory power we briefly mention what empirical observations they can reflect. However, we do not discuss the subjects of calibration and validation (for that see e.g. Grazzini and Richiardi 2015, Grazzini et al. 2017, and Lamperti et al. 2018).

The review of the selected models facilitates the understanding of agent-based macro models and the presentation of the divergent assumptions used by the researchers of this school to create models. It is worth mentioning, however, that other models also exist, which are more or less similar to one another and to the models to be presented, and maybe one of these other models will become the 
prevailing one in the future. Caiani et al. (2016), for example, describe a stockflow consistent model that they expressly intend to use as a benchmark for future models, and they also present a method that can be applied for determining the initial values.

Chiarella and Di Guilmi (2011) examine the transmission of the fragility of the financial sector to the real sector in the case of financial crises, then they also look at how various fiscal policy and regulatory steps may affect the outcome of the shocks (Chiarella - Di Guilmi 2012). Salle et al. (2013) in their agent-based model attempt to remain as close to the new Keynesian traditions as possible, while the actors' expectations are determined by simple rules, which also change through learning. Salle (2015) expands it further with information provided by the central bank.

Delli Gatti et al. (2010) model the financial accelerator, where lending networks evolve between the individual companies and banks. Riccetti et al. (2013) completed this model with multi-period loans, while Riccetti et al. (2016) introduced companies' market capitalisation, and also carried out monetary policy examinations.

In spite of its relatively simple assumptions, the model of Popoyan et al. (2017) is already able to examine the interaction of monetary and macroprudential policies, and in respect of the banking sector the significance of research of this kind is increasing. Their model is based on an earlier version of the model of Ashraf et al. (2017).

Krug (2018) also examines the interaction of monetary policy and macroprudential policy, and the corporate sector is based on Stolzenburg's (2015) agent-based, Solow-type growth model.

\section{Macroeconomics from the bottom-up}

Delli Gatti et al. (2011) wrote a book on their agent-based model entitled Macroeconomics from the Bottom-up. The bottom-up approach is true for all agentbased models. The objective of the book is to provide an introduction to agentbased modelling, also presenting a prototype model, a simpler version of which can already be found in the work of Delli Gatti et al. (2008). The model already includes a simple lending banking sector as well. Below is a presentation of its version further developed by Assenza et al. (2015), where the banking sector also receives more emphasis.

There are three types of actors in the model: households, firms and banks. Households either make a living from wage income (workers) or from dividend income as owners of firms (capitalists). Each capitalist owns one firm. Distinction is 
made between consumption-good firms ( $C$ firms) and capital-good firms ( $K$ firms). $C$ firms produce the homogeneous consumption good with the help of labour and capital, whereas $K$ firms produce capital goods using labour. Technology is linear in both sectors of production: labour productivity is constant in both sectors, while capital and labour are perfect complements in the consumption-good sector.

Firms and households may also accumulate financial wealth in the form of deposits, and firms may borrow in order to finance production costs or investment if they do not have sufficient financial wealth, i.e. deposits, to cover their expenses during a given period. There is no cash in the model; all financial transactions are carried out through the banking sector. For the time being, the model disregards competition among banks and the liquidity issues of the banking sector. Therefore, as a simplification, in addition to the central bank there is only one commercial bank, but it allows for an adequate examination of the role of lending in cycles. Capitalists have equal shares in the bank.

In total, there are 4 markets in the model: consumption goods market, capital goods market, labour market and credit market. Firms produce the same product in the consumption goods market, but sell it at different prices. Labour is homogeneous, and each firm pays the same amount of wage in all periods. Companies receive loans in the credit market with an interest rate determined on the basis of their riskiness, which also affects the amount that can be borrowed.

During a given period, the sequence of events is the following:

1. Depending on the planned output, companies advertise new vacancies in the labour market if they need more labour than in the previous period. Otherwise, they randomly dismiss as many employees as justified by the lower production.

2. The labour market opens: the unemployed randomly contact a determined number of firms, and they are employed by the first firm where there is still a vacancy (new employees stay with the given firm until it dismisses them).

3. Based on previous periods' data, the bank estimates a logistic regression for the probability of default of the companies that apply for loans.

4. If a company needs further funds in addition to its deposits for the payment of wages or for its investment costs, it applies for a bank loan. The bank decides on the interest rate on the newly disbursed loan and on the size of the loan that can be granted depending on the riskiness of the company in question.

5. If a company did not receive a large enough loan, it randomly dismisses a sufficient number of its employees to be able to pay the wages of the remaining ones. Production takes place in both sectors, and companies pay their employees' wages. A given percentage of the capital used for production depreciates. 
6. The capital goods market opens: $C$ firms randomly contact a specified number of $K$ firms, and purchase from them until they reach the size of their planned investment (or until the individual $K$ firms run out of their inventories or the $C$ firms run out of money). Capital goods are durable, so unsold capital goods remain in stock (and will be on sale again in the next period).

7. Households decide on their consumption expenditure in the given period.

8. The consumption goods market opens: each household can see the prices of a specified number of firms, and always purchases from the cheapest firm until running out of its money earmarked for consumption (and still there is product for sale at the firms that it contacted randomly). Unsold products are scrapped.

9. The firms pay interest and repay the adequate part of their loans. In the case of positive profit, they pay dividends to their owner.

10. In the case of positive profit, the bank disburses dividends to the capitalists.

11. The $C$ firms put into operation the newly purchased capital goods.

12. To replace firms that went bankrupt, their owners set up new ones from their own savings.

13. The $C$ and $K$ firms decide on the magnitude of production and the price of their product planned for the next period, and $C$ firms also decide on the size of the planned investment.

In deciding on production and pricing in a given period, consumption-good firms take into account how the price of their product in the last period compared to the average price and whether there was excess demand for or oversupply of their product. In a given period, a firm changes either the magnitude of the planned production or the pricing. For example, if a firm in the last period sold at a price that was higher than the average, and still there was excess demand for its product, in the next period it plans to increase its output in proportion to the size of the excess demand, whereas if there was excess demand for its products while selling at a lower price than the average, the firm plans to raise the price and not its production. $K$ firms also decide on production and pricing based on a similar logic.

When deciding on investment, firms take into account how much capital on average they had to use for production during the previous periods (with exponential weighting). The model comprises a long-term rate of capital utilisation, and firms invest as much as necessary to be able to produce with a capital utilisation that complies with this rate. The rate of capital utilisation is less than one, as a result of which firms can expand their production in the short run if needed. 
A household's income in a given period consists of earned income or - in the case of capitalists - of dividends received from their firm (and the bank). When households decide on their consumption expenditure, they estimate their permanent income as the exponentially weighted average of the previous periods' incomes. Their consumption expenditure equals their permanent income and a certain proportion of their financial savings.

Households and companies keep all of their financial assets on an account held with the commercial bank. The bank does not pay any interest on the deposits, but by creating deposits it may extend loans, for which the bank charges a specific interest. In the case of the $C$ and $K$ firms, based on previous observations, the bank estimates a logistic regression for the probability of default using the individual firms' leverage. The resulting logistic regression systematically underestimates the probability of default in the case of firms that are about to go bankrupt (where the leverage ratio is too high). Firms may borrow every year, and they repay these loans separately, at the interest rate specified upon borrowing. In the case of all loans, a decreasing proportion of the original amount is repaid in the individual periods. When the bank determines the interest rate upon extending the loan, it takes into account the interest incomes expected during repayment as well as the expected principal loss with the help of the aforementioned logistic regression. The capital requirement is not applicable to the bank, but its credit supply is limited by an internal rule: in a given period the maximum amount of new loan disbursed to a company is such that the expected principal loss estimated on the basis of the logistic regression (probability of default $\times$ extended new loan) must not exceed a pre-determined proportion of the bank's equity. Accordingly, growth in the bank's capital stock increases the maximum size of loan that can be extended to a single firm, whereas in the case of a decline in the bank's equity an increasing number of firms may be bound by the credit constraint.

The model is stock-flow consistent; the relations between the individual actors' balance sheets are shown in Table 1. The balance sheet matrix reveals that the individual actors' financial wealth is coupled with the debt of other actors in the model. Therefore, the initial balance sheet data included in the individual agents' balance sheets also have to be given in a way that they should be in conformity with one another at the aggregate level. Following that, by applying quadruple entry accounting it can be ensured that the balance sheet relations are met at the aggregate level as well. 


\section{Table 1}

Balance sheet matrix summarising the balance sheet items of the different types of agents

\begin{tabular}{l|c|c|c|c|c|c}
$\begin{array}{c}\text { Balance sheet } \\
\text { item }\end{array}$ & Households & C firms & K firms & Bank & $\begin{array}{c}\text { Central } \\
\text { bank }\end{array}$ & Total \\
\hline Capital & & $K$ & & & & $K$ \\
\hline Inventories & & $\Delta^{C}$ & $\Delta^{K}$ & & & $\Delta$ \\
\hline Deposits & $D^{H}$ & $D^{C}$ & $D^{K}$ & $-D$ & & 0 \\
\hline Reserves & & & & $R^{B}$ & $-R^{B}$ & 0 \\
\hline Loans & & $-L^{C}$ & $-L^{K}$ & $L$ & & 0 \\
\hline $\begin{array}{l}\text { Government } \\
\text { bonds }\end{array}$ & & & & & $B$ & $B$ \\
\hline Equity & $-E^{H}$ & $-E^{C}$ & $-E^{K}$ & $-E^{B}$ & & $-(K+\Delta+B)$ \\
\hline
\end{tabular}

Note: Negative values constitute the liabilities side of the individual actors' balance sheets, whereas the positive values represent the assets side. $K=$ physical capital at book value, $\Delta=$ inventories, $D=$ deposit, $R=$ reserves, $L=l o a n, B=$ government bond, $E=$ equity (financial wealth in the case of households)

Source: Assenza et al. (2015)

In the model, slight oscillations appear erratically around the long-term GDP, interrupted sometimes by significant downturns, with slow recovery. Comparing the GDP, investment, consumption and unemployment time series of the United States with the relevant time series of the model, we receive similar standard deviations and autocorrelations for the HP-filtered cyclical terms of the individual variables (there is only a major difference in the standard deviation of investment, which is double the empirical value in the model). The correlations with GDP of the lags of the individual variables also show developments similar to empirical observations.

Based on the model, by examining the flow of liquidity between sectors it is easy to understand the outbreak of major crises: prior to the outbreak of the crisis, $C$ firms have 30 per cent of the liquidity that is in the system, whereas during the big crisis it declines to 5 per cent, while liquidity at $K$ firms increases from 20 per cent to 60 per cent. During the upturn, $C$ firms invest more and more, and the demand for capital goods increases, so their price also starts to rise. In parallel with this, the liquidity of $C$ firms declines with the increase in their investment expenditures. Moreover, they have to take out more and more loans for that. With increasing the indebtedness of $C$ firms, risks build up in the sector, the bank lends at increasingly high interest rates, and in addition, due to the vulnerability, for more and more firms it limits the size of the loans granted. This results in a fall in aggregate demand, which increases firm leverage and the probability of default through the decline in profits, thus further reducing bank lending. This mechanism exacerbates the recession. Finally, outstanding debt starts to decline in the consumption sector during the crisis, then the share of $C$ firms in liquidity begins to rise, and bank lending also starts to increase as a result of the sounder structure. 


\section{Real estate price bubbles and business cycles}

Supported by the European Union, the development of the EURACE model started in 2006 with the original aim of creating an agent-based model with a high number of agents, depicting the whole European Union. Due to its complexity and the required high computational capacity, programming for implementation of the model is being done in an environment developed especially for this purpose, called FLAME (Flexible Large-scale Agent Modelling Environment). Deissenberg et al. (2008) present the planned building stones of the model. The final model would comprise all the Member States, with the corporations, households, shops and other agents distributed in space. In addition, the EU is planned to be examined as an open economy, and energy would also be taken into account among the inputs. Agents' decisions may even cover daily activities. The final model is not ready yet, but various articles present some of the model versions of EURACE (e.g. Cincotti et al. 2012, Raberto et al. 2012, Holcombe et al. 2013).

This chapter presents the model called ICEACE (Erlingsson et al. 2014), which contains many simplifications compared to the EURACE model, but expands it to include the housing market and the construction sector. In the model, the effect of mortgage lending on real estate prices is examined, and changes in real estate prices have a direct impact on consumption and construction activity. Accordingly, on the whole, the correlation between mortgage lending and the real economy is examined in the model, while financial stability questions related to mortgage lending are also analysed.

Actors in the model are producers (consumption-good firms, construction firms), commercial banks and households as well as an equity fund, a central bank and a government. Both firms and households may borrow.

Both consumption-good firms and construction firms use labour for their production, based on linear technology. All companies have physical capital as well, the level of which is constant. In the case of consumption-good firms, it does not affect production, but the value of physical capital has an impact on the size of equity. In the case of construction firms, the size of physical capital functions as an upper limit for production. Firms may become indebted, but they do not borrow directly for production. They borrow to be able to pay dividends when liquidity is insufficient and also to be able to pay their interest expenditures. Regarding the loans, they do not repay them; they always only pay the interest on the principal.

Consumption-good firms price on the basis of unit cost, but the unit cost includes interest expenditures as well. Each consumption-good firm adds the same markup to its own unit cost. Every month, firms try to produce as much as necessary to be able to meet the expected demand taking into account their inventories remaining 
from the previous period. Expected demand corresponds to the sales in the previous period, but if there are no remaining inventories, expected demand is increased to a specific degree. In order to avoid unnecessary oscillations, planned production is also adjusted with the help of a relatively simple formula.

In the housing market, homogeneous housing units are exchanged, purchased by households. The sellers are households and construction firms. Construction firms decide on new production every month, but completing one unit takes 12 months. The production rule is very simple: in the case of rising housing prices the individual firms randomly increase their respective production level, which is a random integer between their current production and the maximum production level determined by their physical capital, and in the case of declining housing prices it is a random integer between 1 and their current production level. Accordingly, when housing prices grow, individual production and aggregate production also increase, and when housing prices decrease, production also declines. Construction firms place the newly completed units as well as previously completed but not yet sold units on the market. Households will be sellers with determined probability in a given month (normal sellers), and they will be buyers as well with the same probability. In addition, households also have to take a unit to the market (they have to try to liquidate it) if they become too risky debtors, which is the case when their quarterly credit cost exceeds a certain percentage of their previous quarter's income. Seller households also take one unit to the market each, and each buyer also purchases one unit in a given month. Construction firms and the randomly selected seller households take their units to the market with a markup originating from even distribution, and in the market they add the markup to the average price of the previous period's transactions. The households forced to liquidate choose a price below the average price of the previous period's transactions from even distribution. The households selected for purchasing come one after the other in a random order, and they always buy the cheapest unit that is still for sale. If the given buyer does not have sufficient liquidity, he applies for a mortgage loan from a bank chosen by him. He receives the loan if the sum of the instalments of his outstanding loans and of the new loan does not exceed a pre-determined part of his quarterly income. The mortgage loans are variable-rate ones, but with fixed maturity.

Households decide on their consumption expenditure on the basis of the bufferstock theory every month (Carroll 2001, Deaton 1992), for which they take their quarterly net income reduced by the instalments as a basis. However, consumption calculated on the basis of the buffer-stock theory is adjusted for the wealth effect stemming from the changes in real estate prices, i.e. they will consume more if real estate prices rise, and less when real estate prices decline.

Banks can only lend if their equity exceeds a part of the loans they extended, i.e. there is a capital requirement in the model. If the capital of the individual 
borrowing companies is relatively too low or if certain households' repayment burden is relatively too high, banks write off an adequate portion of the loans concerned, which reduces their equity and thus their credit supply as well.

Every month, the central bank decides on the base rate using a Taylor rule. The government collects taxes, and provides unemployment benefit and general transfers to households. It may change their amounts from time to time, but strives to achieve a break-even balance.

Firms and banks pay dividend to the equity fund, and the equity fund distributes it among households and may provide funding from it to firms that have not received loans from commercial banks but can still be considered well capitalised.

Certain events in the model take place with quarterly frequency, others with monthly or weekly frequency. The events of a quarter can be divided into two: monthly-frequency events take place first, followed by the steps closing the quarter. Accordingly, the sequence of events is as follows:

Monthly-frequency events (three times in succession within one quarter):

a. Firms (including construction companies) decide on the level of production planned for the given month and on the prices, and determine the amount of labour required for the planned production.

b. The events listed below follow one another in the labour market:

i. The firms that want to increase their labour utilisation raise the wage offered by them by a certain percentage. They offer jobs for the vacancies.

ii. The firms that want to reduce their use of labour dismiss an adequate number of employees (who become temporarily unemployed).

iii. Every employee may leave their workplace with specified probability, looking for higher salary. Firms offer new jobs for the resulting vacancies. These employees accept the best paid jobs one by one (until there is a vacancy offered).

iv. Unemployed households accept the best paid jobs one by one (until there is a vacancy offered). 
c. The events listed below follow one another in the housing market:

i. Construction firms place their completed units on the market, and the households selected randomly to be sellers as well as the households obliged to fire sale place one unit each on the market at an adequate price.

ii. One after the other, the randomly selected buyers purchase the cheapest available unit, provided that they have sufficient liquidity or they are able to take out a mortgage loan. If the seller had a mortgage loan, he reduces his principal debt from the income.

d. Households determine their monthly consumption expenditure.

e. Consumption-good firms determine the prices of their products.

f. Households consume every week (four times in a row): arranging them in random order every week, one after the other they try to spend the relevant portion of their monthly consumption expenditure at a randomly selected company (provided that the given company has enough products). The lower the price of a company's product, the higher the probability that households will choose the given company. Unsold products remain in stock.

g. Employed households receive wages from their respective employer companies, and pay income tax to the state, whereas the unemployed receive unemployment benefit from the state. Each household receives the same amount of general transfer from the state.

h. Production takes place using the employed labour: the produced consumer goods are stockpiled, and the housing units whose construction started reach a state one month ahead (if adequate labour is used). The completed products and units become part of the inventories.

i. The central bank changes the base rate.

End-of-quarter events:

a. Households pay instalments to banks. The adequate part of the loans of households with too high instalments is written off. Banks change the mortgage interest rates depending on the base rate.

b. Firms apply for loans if they do not have sufficient liquidity for dividend and interest payments.

c. If a firm has not received a sufficient amount of loan, it reduces the intended dividend disbursement, and applies for capital to the equity fund. 
d. If a firm was also unable to receive funds from the equity fund, it goes through an illiquidity procedure, during which a part of its debt is written off. In the case of firms with negative equity the entire debt is written off, and new firms enter the market instead of them.

e. The firms pay interest to the banks, and the companies and banks pay dividend to the equity fund.

f. The equity fund pays dividend to the households, and the households pay taxes on the dividend income.

g. The government changes the rates of taxes and degree of transfers.

In the model, households may only receive a mortgage loan if the sum of the instalments including the new loan does not exceed a certain $(\beta)$ part of their income. Accordingly, higher $\beta$ means riskier, while lower $\beta$ represents more cautious bank lending. The model was run with several $\beta$ values, and the higher ones resulted in higher house prices and more volatile GDP. In the case of a sufficiently high $\beta$, the model generated business and housing price cycles as well in an endogenous manner, whereas the higher $\beta$ resulted in higher fluctuations. This is attributable to the feedback of mortgage lending to the housing market and the real economy. In the case of a higher $\beta$, an increasing number of households can purchase more and more housing units in the housing market, initially pushing up the housing prices in every period. The rise in housing prices affects the real economy in two ways: firstly, as a result of the price increases, construction firms build more, and boost their labour demand and the wages paid, which adds to households' consumption. Secondly, the rise in housing prices also encourages households to consume more through the wealth effect. As a result of the increased consumption, not only construction firms but consumption-good firms also raise their production. The looser the credit constraints, the faster the GDP growth is initially. However, during the upswing, in parallel with the rise in housing prices, households become increasingly indebted as a result of purchasing increasingly expensive housing units. During the upswing, the central bank also raises the base rate, resulting in further growth in households' instalment burdens. As households consume on the basis of their net quarterly income reduced by the instalment, after some time the economic growth and the wealth effect become unable to offset the negative impact of the increase in instalments on consumption. Moreover, in the case of certain households the instalment may become so high with the increase in the base rate that they may be forced to liquidate a housing unit, or they may even become non-performing, especially if they become unemployed. As a result of fire sales, housing prices start to fall, which deepens the recession through the decline in construction activity and the wealth effect. The first recession mainly results in households' becoming non-performing, which is less typical of companies, although 
their capital declines. During the second cycle, the weakened firms amplify the cycle: following the first recession, with the normalisation of housing prices and a decline in households' indebtedness, a new growth period may start, but the firms begin the second cycle with lower capital in the model. When the economy turns into recession again, in addition to households, firms also become increasingly non-performing, which further erodes the lending capacity of commercial banks through a major fall in the equity of the banking sector, and deepens the recession even further.

The model highlights the feedbacks between mortgage lending and the real economy well, but at the same time the modelling of the housing market disregards many frictions, assuming that households increase or reduce their housing wealth by one unit at a time. Nevertheless, there are agent-based housing market models, in which complete real estates are exchanged. Axtell et al. (2014) model the housing market of Washington, D.C. on the basis of actually observed transactions, and their model also results in the cyclical change of housing prices. Baptista et al. (2016) also model the sale and purchase of complete homes instead of parts. They distinguish buy-to-let investment, and in their model the presence of investors results in the amplification of housing price cycles. Mérő and Vágó (2018) built a demand-led housing market model based on Hungarian data. In addition to generating housing price cycles they examined the effect of the macroprudential instruments that regulate the lending for housing. All the three models generate households and/or homes setting out from micro databases. Although the latter models use more realistic assumptions regarding the housing market, for the time being, real economy feedback is missing from them.

\section{Credit cycles and countercyclical capital buffer}

Dosi et al. (2015) present an agent-based model in which demand rests on Keynesian foundations, while technological development rests on Schumpeterian foundations, and in which they can analyse the effects of both fiscal and monetary policy decisions. Dosi et al. (2006) present the first model version in which the business cycles already evolve in an endogenous manner. This model was expanded in several steps (Dosi et al. 2008, 2010, 2013). ${ }^{1}$ Hosszú and Mérö (2017) took the version published in 2015 as a basis for elaborating a model in which they were able to generate longer lending cycles than business cycles, as is observed empirically as well (Drehmann et al. 2012). They simplified some of the assumptions of the model, but made lending more complex. Due to the detailed banking sector and the generation of credit cycles this version is presented below.

\footnotetext{
${ }^{1}$ Regarding the further versions of the model, see e.g. Dosi et al. $(2017 a, 2017 b)$.
} 
The model (similarly to the other models presented) contains one consumption good, which is produced by heterogeneous firms and can be sold at different prices. The consumption good is produced with the help of labour and physical capital. The capital is produced by heterogeneous capital-good firms using labour, and in the different periods they are able to produce capital of various productivity. Households offer their homogeneous workforce to consumption-good and capitalgood firms, and consume. Consumption-good firms may take short- and longterm loans from commercial banks, although the latter are represented by one bank, considering that the model does not examine the vulnerability of individual banks or the competition among banks. In addition to market participants, the model contains three authorities: central bank, government and macroprudential authority. The central bank acts as lender of last resort, but keeps the base rate at an unchanged level. The government collects taxes and gives unemployment benefit to the unemployed households, and helps the commercial bank in the case of bankruptcy. The macroprudential authority determines the countercyclical capital buffer rate in all periods. Monetary policy and fiscal policy are exogenous, and the model puts the emphasis on the examination of the macroprudential policy, which can be examined due to the fact that the model generates credit cycles of adequate length (even as long as 20-25 years) (cf. Schüler et al. 2015).

As in the other two models presented, there is no cash in this model either; both firms and households keep their money in deposits at the commercial bank, while the account of the state is managed by the central bank. In the case of the state's indebtedness, both the central bank and the commercial bank may hold government bonds.

Consumption-good firms produce using capital and labour. Each unit of capital allows the production of one unit of consumption good, i.e. the capital stock determines the capacity of the consumption-good firm. However, there may be differences in productivity across the individual capital goods, which shows how many units of labour are required for producing the consumption good using the given capital. A consumption-good firm always purchases capital from the same capital-good firm, but the company it is in contact with may offer capital goods of higher and higher productivity in the various periods.

Firms' production decision depends on the demand in the previous periods. They quantify their expectation regarding the demand in the given period accordingly, and they try to produce enough to have some surplus above the expected demand (however, the unsold stocks cannot be taken over to the next period). If they cannot achieve the production level planned for the given period due to insufficiency of their capital stock, they have expansion investment demand. However, in addition to expansion investment demand, replacement investment is also possible for them, which means the replacement of the less efficient capital stock, and thus their unit 
cost will decline. The size of the replacement investment is determined on the basis of a simple rule: they try to replace that part of their capital stock with capital available for them in the given period in the case of which the saving on the unit cost is recovered within a certain period of time.

Labour is homogeneous, and wage is determined at the macro level, so each firm pays the same amount of wage. Consumption-good firms have to pay the wage and the investment costs before they realise income from the production of the given period. Based on the planned production and investment, consumption-good firms quantify their expenses for the given period, and if they do not have sufficient deposits to cover these expenses, they apply for bank loan: they apply for shortterm working capital loan to cover labour costs and for long-term investment loans to cover investment.

Capital-good firms receive the price of the capital good together with the order, and thus they do not have any liquidity issues, and they do not borrow. The technology of all capital-good firms is hit by a small idiosyncratic positive shock, as a result of which the efficiency of the capital produced by them improves to different degrees. At the same time, with a certain probability, firms may copy the technology of another, randomly chosen company. In addition to the idiosyncratic shock, with a low probability, the economy may also be hit by a larger exogenous shock as well, which improves the technology of a randomly chosen firm. However, as a result of learning (copying), this technology slowly spreads in the economy.

There are four ways for households to gain income: their primary income is the wage, but they are also the owners of the firms and the commercial bank, and thus they may receive dividend income from the profits of the firms and the bank. If they are unemployed, they receive unemployment benefit from the state, and the bank credits them with interest on their savings (which mean their bank deposits). In each period, households spend a certain portion of their permanent income on consumption, and they determine their permanent income as the exponentially weighted average of the previous periods' income (taking account of the sources of income listed above). Consumption expenditures are distributed among the individual firms according to their market shares. The market shares of firms depend on the relative price of the good produced by them as well as on the earlier market share. The former condition facilitates competition, while the latter one takes stickiness into the system.

Consumption-good firms compute the average labour cost they can produce the product at, and they add some markup, the degree of which may vary. If a company was able to significantly reduce the unit cost as a result of its replacement investment, it applies a higher markup, but in a way to keep the price of its product competitive. This higher markup declines during an autoregressive process. As 
a result, the increase in productivity initially raises the profitability of the individual companies, before feeding through into real wages with the decline in the markup.

The lending activity of the commercial bank is regulated by the capital requirement, and the latter also contains the countercyclical capital buffer rate. The macroprudential authority determines the value of the countercyclical capital buffer rate $\left(C C B_{t}\right)$ for the given period in line with the Basel III requirements; namely, in the case of expansion, on the basis of the previous period's credit gap $\left(G A P_{t-1}\right)$ :

$$
C C B_{t}=\left\{\begin{array}{c}
0 \%, \text { if } G A P_{t-1} \leq 2 \% \\
2.5 *\left(G A P_{t-1}-2 \%\right) / 8 \%, \text { if } 2 \%<G A P_{t-1} \leq 10 \% \\
2,5 \%, \text { if } 10 \%<G A P_{t-1}
\end{array}\right.
$$

The capital buffer is eased by the macroprudential authority if there is a decline of at least 5 percentage points in the credit-to-GDP ratio (compared to the trend of the GDP).

The commercial bank ranks the firms on the basis of the return on sales, and satisfies the loan applications on the basis of this ranking, as long as its equity allows it. However, first it disburses working capital loans, and switches over to the disbursement of investment loans when it has satisfied demand for working capital loans at all of the companies. As a result, if the credit supply is tight, the volume of investment loans declines first, leading to higher volatility in investment. At the end of each period, firms repay the working capital loan with interest on it, but in the case of investment loans they only pay off a certain percentage of the outstanding debt. If, however, a company's loans outstanding exceed a given percentage of its production costs, or if the growth rate of the loans outstanding is too high, it prepays a certain amount depending on its liquidity.

In the model, each period corresponds to a quarter. For transparency, in the case of this model as well we disclose the sequence of events in the individual periods, also highlighting some further details of the model: ${ }^{2}$

1. Nominal wages are defined for the given period. The macroprudential authority determines the level of the countercyclical capital buffer.

2. Consumption-good firms set their prices.

3. The technology of capital-good firms sustains an idiosyncratic shock; the capitalgood firms determine the price of the capital produced by them and send out the price and the technological characteristics of their capital goods to the consumption-good firms in contact with them.

\footnotetext{
${ }^{2}$ The list was taken from the original article word for word.
} 
4. The bank determines the volume of loans that can be still disbursed and ranks the firms based on their creditworthiness (profitability).

5. Consumption-good firms define how much to produce during a given period and how much to invest for the purposes of capacity increase and replacement (productivity increase). Depending on corporate deposits and the amount of money necessary for production and investment, firms submit their loan applications to the bank.

6. The bank grants loans to the firms in consideration of its credit constraints. Loans are granted on the basis of the pre-defined corporate ranking: firstly, the bank disburses working capital loans required for production during the given period. This is followed by investment loans also based on the firms' ranking.

7. Production: if consumption-good firms received only a portion of the loan amount for which they applied, they first try to achieve the targeted production level and intend to use only the remaining liquid resources for investment, conveying their investment intention to the capital-good firms they are in contact with. Both capital-good firms and consumption-good firms hire the required number of employees and pay wages, while the goods produced are placed in inventory. After production, a part of the consumption-good firms' capital depreciates. The state pays unemployment benefits to the unemployed.

8. Consumption: the market share of consumption-good firms evolves, while households determine their consumption expenditure. Households distribute their consumption expenditures among the various firms based on their market share, but in the event of excess demand, they may even purchase from corporations with excess, ignoring the market share. Firms purchase capital goods, install them and replace the necessary quantity.

9. End-of-period cash flows:

a. the firms pay tax to the state; interest payments in a determined order: the firms pay interest on their loans outstanding at the end of the previous period and on their working capital loans in the given period; the bank receives interest on the government securities it held at the end of the previous period; the bank pays interest on the closing deposit stock of the previous period and on its central bank loan outstanding (if there was any) at the end of the previous period.

b. the firms try to repay the working capital loans, and finally they also repay a specific portion of their closing stock of investment loans for the previous period; 
c. the government bails out the bank if the bank's own funds are insufficient and it fails to comply with regulatory requirements;

d. the firms pay dividends to the households;

e. the bank pays taxes to the government and then pays dividends to the households;

$\mathrm{f}$. at the end of the period, we record the debt owed by the various agents and their interest payment obligations for the next period based on the prevailing interest rates.

In the model, the economic cycles evolve as a result of low-probability but significant exogenous technical shocks, leading to an increase in the GDP growth rate in the medium term. Productivity growth starts from one firm, but as a result of copying the technology it spreads in the economy, and accordingly an increasing number of firms replace some of their respective capital stocks with more efficient capital. The persistence of productivity growth is a result of the spread of the technology. The increased investment demand reduces unemployment and adds to consumption, as a result of which firms carry out not only replacement investment but capacity increasing investment as well, amplifying GDP growth. With a decline in investment, the GDP growth rate also starts to decrease.

During economic expansion, firms have to borrow more for the higher investment. Consequently, long-term loans outstanding increase. However, when GDP growth declines, loans outstanding start to decrease only slowly, and thus in the case of the next economic cycle the firms increase their investment against the background of higher indebtedness, resulting in a further rise in loans outstanding. Accordingly, credit cycles may be longer than economic cycles. During the next upswing, the higher level of loans outstanding imposes a greater repayment burden on companies. However, not every company can afford to offset the repayment burden with the same ease. Loan repayment is typically less difficult for those companies that start replacement investment at the beginning of business cycles (innovators). Their production costs are lower than those of other companies, and therefore their profitability increases, allowing them to offset the repayment burdens. As a result of lower production costs, the innovators' market share grows, as they reduce their markup. By contrast, with their replacement investment the companies that invest later (followers) can only avoid a decline in their market share. As they will not be more efficient than the innovators, their profitability will be lower than that of the innovators. Accordingly, it is more difficult for them to offset the repayment burden, and they repay their long-term loans more slowly. The companies that have weaker technologies and those followers that were more indebted from the outset may go bankrupt after some time, especially when GDP growth starts to 
decelerate. As a result, the equity of the commercial bank declines, leading to a fall in credit supply, and thus fewer companies will have access to investment loans, which reduces aggregate demand, resulting in the bankruptcy of even more companies. The model includes a closed economy, and thus the credit constraint may result in an even larger decline in GDP: while in an open economy some of the credit constraint reduces import demand, in a closed economy the credit constraint is entirely reflected in a decrease in domestic aggregate demand.

In the model, two things may attenuate the recession. Firstly, the government may bail out the commercial bank when its equity is insufficient, and thus the decline in credit supply will be lower. Secondly, the countercyclical capital buffer may also contribute to a lower decline in credit supply during recession, as the released capital buffer allows for the extension of new loans. During the model simulations, the countercyclical capital buffer results in slightly lower average GDP growth: firstly, the capital adequacy ratio may bind the lending activity earlier, and secondly, due to the higher capital requirement the bank pays less dividend, which reduces aggregate demand through the lower consumption of households. Nevertheless, when the countercyclical capital buffer is applied, recessions are also smaller, i.e. the macroprudential instrument under review not only increases the stability of the banking sector, but also reduces the cyclical fluctuations in GDP.

\section{Comments on the models in the light of experiences}

There may be many kinds of agent-based models, although some common features - such as deposit creation by lending and stock-flow consistency - are starting to become standard practices. However, each model has its own world, which is difficult to comprehend at first sight. When setting up DSGE models, in many cases the only question is what equation the authors use to depict the problem under review, while the framework of thinking is practically uniform, and thus the models are easier to understand. Very often the reader can automatically recognise the mechanisms when seeing the structure of the model. However, in the case of agent-based models the mechanisms of the model should be described in a rather detailed manner for complete and sure understanding. It is not enough to just describe the rules, because the readers do not necessarily have sufficient experience to see the set of rules as a coherent entirety. Delli Gatti et al. (2011) published a book about their model, which allowed them to describe the model in detail, with many references to the mechanisms. Nevertheless, in the case of publications in journals it may require troublesome work from the reader to precisely understand the working of the model.

A great advantage of agent-based models is that upon creating the decision-making rules applied they can relatively easily include empirical observations, although 
care needs to be taken as the many applied rules should also remain manageable at the level of the model as a whole. As it is not necessary to keep the model as a whole analytically manageable, the creators of agent-based models are strongly tempted to simultaneously include all kinds of rules that seem to be close to reality in the model. Consequently, the model may become incomprehensible very quickly: although the creator of the model may have an idea about the basic expected results of each rule, the interactions of individual rules need to be understood in detail. In relation to the expansions of the EURACE model it often happens that so many assumptions are included in it at once that the economy is able to show major fluctuations even in a short time. Although the results do not have to be deduced, with the help of some examples it is necessary to think over in the case of each rule what dynamics it may take into the system and why. If we understand the processes, it may also help in the adequate amendment to and complementing of the rules as well. Delli Gatti et al. (2011) and Dosi et al. (2015), on the other hand, use fewer assumptions than the EURACE model, and basically also give more likely results in the case of the variables under review.

In agent-based models, smoothing is important when creating the rules (for example, one company should not want to completely satisfy a surge in demand). If no smoothing is applied, some developments may result in bigger and bigger fluctuations. At the same time, care must also be taken to include automatic stabilisers to a certain extent in the model, which are somehow able to prevent the economy from reaching very extreme values. While rational expectations in DSGE models do not allow the model to become extreme, in the case of agent-based models it is easy to create a model in a way that over time the economy either explodes or disappears. For example, in the model of Hosszú and Mérö (2017), in the case of an inappropriately chosen unemployment benefit any extreme could occur if the indebtedness of the government is not prevented. If the unemployment benefit is too high, aggregate demand may be too high, whereas in the case of too low unemployment benefit aggregate demand may even gradually fade away. Against the background of lower unemployment benefits, this latter mechanism may occur even more often in the model of Dosi et al. (2015): the consumers do not receive dividends, but as a result, their earned income becomes lower on the whole than the total value of the products sold with a markup on the wage cost, and consequently without having any other source of income the consumers would only be able to consume less and less.

As far as the stylised facts reproduced by agent-based models are concerned, the models highlight those results that exist at least in a qualitative manner, but of course it is not mentioned in how many things the results should be closer to reality. Assenza et al. (2015), for example, indicate to what extent the standard deviations and autocorrelations of the various macro variables as well as the correlations 
between the lags in GDP and the other macro variables are similar to the empirical values, but the endogenous recession that evolved in the model is too protracted.

Agent-based models often refer to the fact that the cycles evolve in them in an endogenous manner. There are 100 companies in the model of Delli Gatti et al. (2011), and they point out that the endogenous cycle may be caused by idiosyncratic shocks to companies, as opposed to the exogenous productivity shock of DSGE models. At the same time, the size of companies shows a left-skewed distribution, and some relatively large corporations evolve (in an endogenous manner). If, however, the idiosyncratic shock affects one of the large corporations that accounts for a significant portion of the production, this shock is not necessarily far from an exogenous aggregate shock. Nevertheless, for the development of a recession, vulnerabilities continue to build up in an endogenous manner.

The development of agent-based models poses a major challenge to developers: instead of analytical deductions, it is necessary to analyse the direct effect and interactions of numerous rules, and calibration also often requires hard work. The values of the parameters included in the individual rules have to be fine-tuned, otherwise one easily receives dynamics that are far from reality.

Agent-based models may require lots of calculations. In the case of Assenza et al. (2015) as well as Hosszú and Mérö (2017) there are still relatively few actors: to compute the decisions of a couple hundred agents at the complexity level applied does not require much calculation. However, when the order of magnitude of the number of agents changes considerably (which was set as a target by the EURACE), running a model may take a long time. This may result in problems during both development and calibration. The codes need to be run very many times during development to understand the processes, to try out the many rules and for troubleshooting as well. During calibration, a lot of running is also necessary in order to find the right parameters. And for an appropriate modelling of the banking sector, the number of agents needs to be increased: for example, in each period, adequate observation regarding the companies that went bankrupt is needed, as if only some companies may go bankrupt on average during a period, loan losses may show too high volatility. If one would like to expand the macro model with a housing market as well, many households also need to be included in order to have a sufficient number of transactions in every period.

\section{Summary}

As a result of the crisis, more and more economists started to develop agent-based models, instead of mainstream models. At present, in these models it is easier to simultaneously include frictions concerning the real economy, the housing market and lending. Agent-based models increasingly attempt to include the results of 
behavioural economics in the assumptions applied, in order to make the modelling as realistic as possible. The banking sector is also depicted in a way that deposits are created by lending. Upon examining the risks inherent in lending, one important aspect is to take into account the heterogeneity of debtors, and if heterogeneity is included in the model on the basis of micro databases, real losses can also be quantified in a better founded manner. As a result of these properties, more and more agent-based macro models are being developed, complemented with an increasingly sophisticated financial intermediary system and/or housing market. For the time being, many models reflect some qualitative features, but other models managed to be calibrated for several quantitative correlations as well. Over time these models may become suitable for providing well-founded simulations for regulatory decisions.

\section{References}

Alpanda, S. - Cateau, G. - Meh, C. (2018): A policy model to analyze macroprudential regulations and monetary policy. Canadian Journal of Economics, 51(3): 828-863.

https://doi.org/10.1111/caje.12339

Ashraf, Q. - Gershman, B. - Howitt, P. (2017): Banks, market organization, and macroeconomic performance: An agent-based computational analysis. Journal of Economic Behaviour \& Organization, 135(March): 143-180. https://doi.org/10.1016/j. jebo.2016.12.023

Assenza, T. - Delli Gatti, D. - Grazzini, J. (2015): Emergent dynamics of a macroeconomic agent based model with capital and credit. Journal of Economic Dynamics \& Control, 50(January): 5-28. https://doi.org/10.1016/j.jedc.2014.07.001

Axtell, R. - Farmer, D. - Geanakoplos, J. - Howitt, P. - Carrella, E. - Conlee, B. - Goldstein, J. - Hendrey, M. - Kalikman, P. - Masad, D. - Palmer, N. - Yang, C.-Y. (2014): An AgentBased Model of the Housing Market Bubble in Metropolitan Washington, D. C. Deutsche Bundesbank's Spring Conference on 'Housing markets and the macroeconomy: challenges for monetary policy and financial stability'.

Baptista, R. - Farmer, J.D. - Hinterschweiger, M. - Low, K. - Tang, D. - Uluc, A. (2016): Macroprudential policy in an agent-based model of the UK housing market. Bank of England Staff Working Paper, 619. http://dx.doi.org/10.2139/ssrn.2850414

Benes, J. - Kumhof, M. - Laxton, D. (2014): Financial Crises in DSGE Models: A Prototype Model. IMF Working Papers 14/57. https://doi.org/10.5089/9781475540895.001

Békési, L. - Köber, Cs. - Kucsera, H. - Várnai, T. - Világi, B. (2016): The macroeconomic forecasting model of the MNB. MNB Working Papers, 2016/4. 
Caiani, A. - Godin, A. - Caverzasi, E. - Gallegati, M. (2016): Agent based-stock flow consistent macroeconomics: Towards a benchmark model. Journal of Economic Dynamics \& Control, 69(August): 375-408. https://doi.org/10.1016/j.jedc.2016.06.001

Carroll, C.D. (2001): A theory of the consumption function, with and without liquidity constraints. Journal of Economic Perspectives, 15(3): 23-45. https://doi.org/10.1257/ jep.15.3.23

Chadha, J.S. - Corrado, L. (2012): Macro-prudential policy on liquidity: What does a DSGE model tell us? Journal of Economics and Business, 64(1): 37-62. https://doi.org/10.1016/j. jeconbus.2011.04.004

Chiarella, C. - Di Guilmi, C. (2011): The financial instability hypothesis: A stochastic microfoundation framework. Journal of Economic Dynamics \& Control, 35(8): 1151-1171. https://doi.org/10.1016/j.jedc.2011.02.005

Chiarella, C. - Di Guilmi, C. (2012): The Fiscal Cost of Financial Instability. Studies in Nonlinear Dynamics \& Econometrics, 16(4): 1-29. https://doi.org/10.1515/1558-3708.1970

Christiano, L. - Motto, R. - Rostagno, M. (2010): Financial factors in economic fluctuations. Working Paper Series 1192, European Central Bank.

Christiano, L. - Motto, R. - Rostagno, M. (2014): Risk shocks. American Economic Review, 104(1): 27-65. https://doi.org/10.1257/aer.104.1.27

Cincotti, S. - Raberto, M. - Teglio, A. (2012): The EURACE macroeconomic model and simulator. In: Aoki, M. - Binmore, K. - Deakin, S. - Gintis, H. (ed.): Complexity and Institutions: Markets, Norms and Corporations, 81-106. Palgrave McMillan.

Copeland, M.A. (1949): Social accounting for moneyflows. The Accounting Review, 24(3): 254-264.

Cúrdia, V. - Woodford, M. (2016): Credit frictions and optimal monetary policy. Journal of Monetary Economics, 84(C): 30-65. https://doi.org/10.1016/j.jmoneco.2016.10.003

Deissenberg, C. - van der Hoog, S. - Dawid, H. (2008): EURACE: A massively parallel agentbased model of the European economy. Applied Mathematics and Computation, 204(2): 541-552. https://doi.org/10.1016/j.amc.2008.05.116

Dawid, H. - Delli Gatti, D. (2018): Agent-Based Macroeconomics. Bielefeld Working Papers in Economics and Management, 02-2018. http://dx.doi.org/10.2139/ssrn.3112074

Delli Gatti, D. - Desiderio, S. - Gaffeo, E. - Cirillo, P. - Gallegati, M. (2011): Macroeconomics from the Bottom-up. Springer-Verlag, Italy. https://doi.org/10.1007/978-88-470-1971-3 
Delli Gatti, D. - Gaffeo, E. - Gallegati, M. - Giulioni, G. - Palestrini, A. (2008): Emergent Macroeconomics. An Agent-Based Approach to Business Fluctuations. Springer-Verlag, Italy.

Delli Gatti, D. - Gallegati, M. - Greenwald, B. - Russo, A. - Stiglitz, J. (2010): The financial accelerator in an evolving credit network. Journal of Economic Dynamics \& Control, 34(9): 1627-1650. https://doi.org/10.1016/j.jedc.2010.06.019

De Grauwe, P. (2012): Booms and busts in economic activity. Journal of Economic Behaviour \& Organization, 83(3): 484-504. https://doi.org/10.1016/j.jebo.2012.02.013

Deaton, A. (1992): Household Saving in LDCs: Credit Markets, Insurance and Welfare. The Scandinavian Journal of Economics, 94(2): 253-273. https://doi.org/10.2307/3440451

Dilaver, O. - Jump, R. - Levine, P. (2018): Agent-based macroeconomics and dynamic stochastic general equilibrium models: Where do we go from here? Journal of Economic Surveys, 32(4): 1134-1159. https://doi.org/10.1111/joes.12249

Dosi, G. - Fagiolo, G. - Napoletano, M. - Roventini, A. (2013): Income distribution, credit and fiscal policies in an agent-based Keynesian model. Journal of Economic Dynamics \& Control, 37(8): 1598-1625. https://doi.org/10.1016/j.jedc.2012.11.008

Dosi, G. - Fagiolo, G. - Napoletano, M. - Roventini, A. - Treibich, T. (2015): Fiscal and monetary policies in complex evolving economies. Journal of Economic Dynamics \& Control, 52(March): 166-189. https://doi.org/10.1016/j.jedc.2014.11.014

Dosi, G. - Fagiolo, G. - Roventini, A. (2006): An evolutionary model of endogenous business cycles. Computational Economics, 27(1): 3-34. https://doi.org/10.1007/s10614-005-9014-2

Dosi, G. - Fagiolo, G. - Roventini, A. (2008): The microfoundations of business cycles: an evolutionary, multi-agent model. Journal of Evolutionary Economics, 18(3-4): 413-432. https://doi.org/10.1007/s00191-008-0094-8

Dosi, G. - Fagiolo, G. - Roventini, A. (2010): Schumpeter meeting Keynes: A policy-friendly model of endogenous growth and business cycles. Journal of Economic Dynamics \& Control, 34(9): 1748-1767. https://doi.org/10.1016/j.jedc.2010.06.018

Dosi, G. - Napoletano, M. - Roventini, A. - Treibich, T. (2017a): Micro and macro policies in the Keynes+Schumpeter evolutionary models. Journal of Evolutionary Economics, 27(1): 63-90. https://doi.org/10.1007/s00191-016-0466-4

Dosi, G. - Pereira, M. C. - Roventini, A. - Virgillito, M. (2017b): When more flexibility yields more fragility: The microfoundations of Keynesian aggregate unemployment. Journal of Economic Dynamics \& Control, 81(August): 162-186. https://doi.org/10.1016/j. jedc.2017.02.005 
Drehmann, M. - Borio, C. - Tsatsaronis, K. (2012): Characterising the financial cycle: don't lose sight of the medium term! BIS Working Papers, 380.

Erlingsson, E. - Teglio, A. - Cincotti, S. - Stefansson, H. - Sturluson, J. - Raberto, M. (2014): Housing Market Bubbles and Business Cycles in an Agent-Based Credit Economy. Economics: The Open-Access, Open-Assessment E-Journal, 8, 1-42.

http://dx.doi.org/10.5018/economics-ejournal.ja.2014-8

Fagiolo, G. - Roventini, A. (2017): Macroeconomic Policy in DSGE and Agent-Based Models Redux: New Developments and Challenges Ahead. Journal of Artificial Societies and Social Simulation, 20(1) 1. https://doi.org/10.18564/jasss.3280

Farmer, J. D. - Foley, D. (2009): The economy needs agent-based modelling. Nature, 460(August): 685-686. https://doi.org/10.1038/460685a

Gertler, M. - Kiyotaki, N. (2010): Financial Intermediation and Credit Policy in Business Cycle Analysis. Handbook of Monetary Economics, Volume 3, pp. 547-599. https://doi. org/10.1016/B978-0-444-53238-1.00011-9

Gertler, M. - Karádi, P. (2011): A model of unconventional monetary policy. Journal of Monetary Economics, 58(1): 17-34. https://doi.org/10.1016/j.jmoneco.2010.10.004

Grazzini, J. - Richiardi, M. (2015): Estimation of ergodic agent-based models by simulated minimum distance. Journal of Economic Dynamics \& Control, 51(February): 148-165. https://doi.org/10.1016/j.jedc.2014.10.006

Grazzini, J. - Richiardi, M. - Tsionas, M. (2017): Bayesian estimation of agent-based models. Journal of Economic Dynamics \& Control, 77(April): 26-47. https://doi.org/10.1016/j. jedc.2017.01.014

Godley, W. - Lavoie, M. (2007): Monetary economics - An Integrated Approach to Credit, Money, Income, Production and Wealth. Palgrave MacMillan, New York.

Haldane, A. G. - Turrell, A. E. (2018): An interdisciplinary model for macroeconomics. Oxford Review of Economic Policy, 34(1-2): 219-251. https://doi.org/10.1093/oxrep/grx051

Holcombe, M. - Coakley, S. - Kiran, M. - Chin, S. - Greenough, C. - Worth, D. - Cincotti, S. - Raberto, M. - Teglio, A. - Deissenberg, C. - van der Hoog, S. - Dawid, H. - Gemkow, S. - Harting, P. - Neugart, M. (2013): Large-scale modeling of economic systems. Complex Systems, 22(2): 175-191. https://doi.org/10.25088/ComplexSystems.22.2.175

Hosszú, Zs. - Mérő, B. (2017): Hitelciklusok és anticiklikus tőkepuffer egy ágensalapú keynesi modellben (Credit cycles and the counter-cyclical capital buffer in an agent-based Keynesian model). Közgazdasági Szemle (Economic Review), 64(May): 457-475.

https://doi.org/10.18414/KSZ.2017.5.457 
Jakab, Z. - Kumhof, M. (2015): Banks are not intermediaries of loanable funds - and why this matters. Bank of England Working Papers, No. 529. http://dx.doi.org/10.2139/ ssrn. 2612050

Kaplan, G. - Moll, B. - Violante, G. L. (2018): Monetary Policy According to HANK. American Economic Review, 108(3): 697-743. https://doi.org/10.1257/aer.20160042

Krug, S. (2018): The interaction between monetary and macroprudential policy: should central banks 'lean against the wind' to foster macro-financial stability? Economics: The Open-Access, Open-Assessment E-Journal, 12-7, 1-69.

http://dx.doi.org/10.5018/economics-ejournal.ja.2018-7

Krugman, P. (2011): The Profession and the Crisis. Eastern Economic Journal, 37(3): 307-312. https://doi.org/10.1057/eej.2011.8

Lamperti, F. - Roventini, A. - Sani, A. (2018): Agent-based model calibration using machine learning surrogates. Journal of Economic Dynamics \& Control, 90(C): 366-389. https://doi.org/10.1016/j.jedc.2018.03.011

Lindé, J. - Smets, F. - Wouters, R. (2016): Challenges for Central Banks' Macro Models, in: Taylor, J.B. - Uhlig, H. (ed.): Handbook of Macroeconomics. North Holland, Volume 2, 2185-2262. https://doi.org/10.1016/bs.hesmac.2016.04.009

Mérő, B. - Vágó, N. (2018): Keresletvezérelt lakáspiaci modell a lakáshitelezést szabályozó makro prudenciális eszközök tanulmányozására (A demand-led model of the housing market for studying the macro-prudential means of regulating housing loans). Közgazdasági Szemle (Economic Review), 65(November): 1115-1153. http://dx.doi.org/10.18414/ KSZ.2018.11.1115

McLeay, M. - Radia, A. - Thomas, R. (2014): Money creation in the modern economy. Bank of England, Quarterly Bulletin 2014Q1, 14-27.

Pyka, A. - Fagiolo, G. (2007): Agent-based modelling: A methodology for Neo-Schumpeterian economics, in: Hanusch, H. - Pyka, A. (ed.): The Elgar Companion to Neo-Schumpeterian Economics. Cheltenham, Edward Elgar Publishing.

Popoyan, L. - Napoletano, M. - Roventini, A. (2017): Taming macroeconomic instability: Monetary and macro-prudential policy interactions in an agent-based model. Journal of Economic Behaviour \& Organization, 134(February): 117-140. https://doi.org/10.1016/j. jebo.2016.12.017

Raberto, M. - Teglio, A. - Cincotti, S. (2012): Debt, Deleveraging and Business Cycles. An Agent-Based Perspective. Economics: The Open-Access, Open-Assessment E-Journal, 6, 1-49. http://dx.doi.org/10.5018/economics-ejournal.ja.2012-27 
Riccetti, L. - Russo, A. - Gallegati, M. (2013): Leveraged network-based financial accelerator. Journal of Economic Dynamics \& Control, 37(8): 1626-1640. https://doi.org/10.1016/j. jedc.2013.02.008

Riccetti, L. - Russo, A. - Gallegati, M. (2016): Stock market dynamics, leveraged networkbased financial accelerator and monetary policy. International Review of Economics \& Finance, 43(May): 509-524. https://doi.org/10.1016/j.iref.2016.01.012

Romer, P. (2016): The Trouble With Macroeconomics. The American Economist, under publication. https://paulromer.net/trouble-with-macroeconomics-update/. Downloaded: 15 April 2018.

Salle, I. (2015): Modeling expectations in agent-based models - An application to central bank's communication and monetary policy. Economic Modelling, 46(April): 130-141. https://doi.org/10.1016/j.econmod.2014.12.040

Salle, I. - Yildizoglu, M. - Sénégas, M.-A. (2013): Inflation targeting in a learning economy: An ABM perspective. Economic Modelling, 34(August): 114-128. https://doi.org/10.1016/j. econmod.2013.01.031

Schüler, Y. - Hiebert, P. - Peltonen, T. (2015): Characterising the Financial Cycle: A Multivariate and Time-Varying Approach. ECB Working Paper, 1846.

Stiglitz, J. (2011): Rethinking Macroeconomics: What Failed, and How to Repair It. Journal of the European Economic Association, 9(4): 591-645. https://doi.org/10.1111/j.15424774.2011.01030.x

Stolzenburg, U. (2015): The agent-based Solow growth model with endogenous business cycles. Economics Working Papers 2015-01, Christian-Albrechts-University of Kiel, Department of Economics.

Tesfatsion, L. - Judd, K. (ed.) (2006): Handbook of Computational Economics. Volume 2: Agent-Based Computational Economics. North Holland. 